\title{
Herbal melanin induces interleukin-1 $\beta$ secretion and production by human THP-1 monocytes via Toll-like receptor 2 and p38 MAPK activation
}

\author{
ADILA EL-OBEID ${ }^{1-3}$, WESAM BIN YAHYA ${ }^{4,5}$, BADER ALMUZZAINI $^{5}$, ABEER AL TUWAIJRI $^{5}$, \\ MARIA NAJDI $^{4,6}$, ADIL HASSIB $^{7}$ and SABINE MATOU-NASRI ${ }^{4,5}$
}

\footnotetext{
${ }^{1}$ Biobank, King Abdullah International Medical Research Center, Riyadh 11481, Saudi Arabia; ${ }^{2}$ School of Pharmacy, Ahfad University for Women, Omdurman, Khartoum 11111, Sudan; ${ }^{3}$ Department of Genetics and Pathology, Rudbeck Laboratory, Uppsala University Hospital, 75237 Uppsala, Sweden; ${ }^{4}$ Cell and Gene Therapy Group, Medical Genomics Research Department, ${ }^{5}$ Medical Genomics Research Department, King Abdullah International Medical Research Center, Ministry of National Guard-Health Affairs, King Saud bin Abdulaziz University for Health Sciences, Riyadh 11481;

${ }^{6}$ Postgraduate Program, King Saud University, Riyadh 12372, Saudi Arabia;

${ }^{7}$ Department of Physics, Faculty of Science, University of Khartoum, Khartoum 11111, Sudan
}

Received August 30, 2020; Accepted March 26, 2021

DOI: $10.3892 / \mathrm{etm} .2021 .10515$

\begin{abstract}
Herbal melanin (HM), extracted from Nigella sativa, is known for its immunogenic properties through the modulation of cytokine production via Toll-like receptor (TLR)4. TLRs play a crucial role in the host defense through the regulation of innate and adaptive immune responses. However, the potential effect of $\mathrm{HM}$ on the production of interleukin-1 $\beta$ (IL-1 $\beta$ ), the main immunoregulatory cytokine secreted by activated monocytes, has not been reported. The present study aimed to investigate the effects of HM on IL-1 $\beta$ secretion and production, detected by enzyme-linked immunosorbent assay, western blotting and mRNA expression monitored by reverse transcription-PCR, in human monocytes and a monocytic cell line, THP-1. Signaling pathways involved in the HM-induced IL-1 $\beta$ production was investigated in the THP-1 cells. It was shown that HM upregulated the IL-1 $\beta$ mRNA in the THP-1 cells and induced the secretion of IL-1 $\beta$ in the monocytes and THP- 1 cells, in a dose-dependent manner, compared to the untreated cells. HM increased the protein expression of IL-1 $\beta$, TLR2, the main receptor for IL-1 $\beta$ production, and activated $\mathrm{p} 38$ mitogen-activated protein kinase (MAPK), a key mediator for stress-induced IL-1 $\beta$ gene
\end{abstract}

Correspondence to: Dr Sabine Matou-Nasri, Cell and Gene Therapy Group, Medical Genomics Research Department, King Abdullah International Medical Research Center, Ministry of National Guard-Health Affairs, King Saud bin Abdulaziz University for Health Sciences, P.O. Box 22490, Riyadh 11481, Saudi Arabia E-mail: matouepnasrisa@ngha.med.sa

Key words: herbal melanin, monocytes, THP-1, interleukin, Toll-like receptor expression. The blockade of the p38 MAPK pathway, with the pharmacological inhibitor SB202190, and TLR2 receptor with a neutralization antibody, resulted in the decrease of HM-induced IL-1 $\beta$ production in THP-1 cells. The TLR4 receptor blockade also decreased HM-induced IL-1 $\beta$ production, but to a lesser extent than TLR2 blockade. In conclusion, the present study demonstrated that HM stimulates IL-1 $\beta$ production in monocytes and THP-1 cells, in a TLR2/p38 MAPK pathway-dependent manner, suggesting promising immunoregulatory potentials of HM against inflammatory-associated diseases.

\section{Introduction}

Melanins are dark-brown to black pigments found in animals, plants and microorganisms $(1,2)$. The presence of melanin has been associated with various immune responses in animals, plants and invertebrates (3-6). Nigella sativa $\mathrm{L}$. is an herbaceous plant, traditionally used in folk medicine in the Middle East and South East Asia. Various research/clinical groups studied the effect of the total extracts of Nigella sativa on the immune system $(7,8)$. Melanin extracted from the seed coats of Nigella sativa have been chemically described and characterized $(9,10)$. Previously, a similarity was reported between the biological effects of herbal melanin (HM) extract and bacterial endotoxin-lipopolysaccharide (LPS) in modulating the production of interleukin (IL)-6, tumor necrosis factor (TNF) $\alpha$ and vascular endothelial growth factor (VEGF) through Toll-like receptor (TLR) 4 and nuclear factor (NF)- $\mathrm{kB}$ activation, the main pathway for cytokine production (10-12). As a potential alternative medicinal plant-based drug for the treatment of inflammatory-associated diseases, the assessment of the potential immunoregulatory effects of HM on the production of major pro- and anti-inflammatory cytokines such as IL-1 $\beta$ is required. 
IL-1, an important inflammatory and immunoregulatory cytokine, is usually expressed by activated monocytes and macrophages $(13,14)$. IL-1 is composed of two distinct proteins, IL-1 $\alpha$ and IL-1 $\beta$ (14). IL- $1 \beta$ is a $35-k D$ a secreted protein induced in response to a variety of stimuli including LPS, phorbol myristate acetate and IL- $1 \beta$ itself $(14,15)$. IL- $1 \beta$ possesses a broad range of biological activities, such as the resolution of inflammation through the induction of apoptosis in active immune cells (16). The role of IL-1 $\beta$ varies greatly, depending on the tissues and organs involved and the stage of inflammation (17). Elevated and decreased levels of IL-1 $\beta$ have been implicated in various acute inflammatory-associated diseases, such as bacterial meningitis and human immunodeficiency virus type 1-seropositive hemophiliacs $(18,19)$.

TLRs are a family of evolutionarily conserved receptors with a crucial role in early host defense against pathogens, through the regulation of both the innate and adaptive immune responses. TLRs are capable of recognizing pathogen-associated molecule patterns. Thirteen TLRs and their respective ligands have been identified in mammals, including TLR2, TLR4 and LPS, the main ligand (20-22). The TLR signaling pathway plays a role in regulating cytokine production, including the production of IL-1 $\beta$ (19), through the activation of the NF- $\mathrm{BB}$ pathway $(23,24)$ and the $\mathrm{p} 38$ mitogen-activated protein kinase (MAPK) pathway (25).

In the present study, the effect of HM on IL-1 $\beta$ secretion and production was investigated in human monocytes and THP-1 cells. The requirement of TLR4, TLR2 receptor and the p38 MAPK pathway activation for HM-induced IL-1 $\beta$ production was also demonstrated in THP-1 cells, after using an anti-TLR neutralizing antibody and the p38 MAPK pharmacological inhibitor, respectively.

\section{Materials and methods}

Herbal melanin preparation. The detailed extraction, characterization and stock solution preparation for the experimental use of the melanin from Nigella sativa L. seed coats were conducted according to the methods previously described (10).

Human monocyte isolation. Peripheral blood mononuclear cells (PBMC) were obtained and cultured from blood collected from healthy donors who voluntarily consented, as previously described (11). Briefly, cells were separated by a Ficoll-Paque ${ }^{\circledR}$ (GE Healthcare) density gradient centrifugation at $400 \mathrm{x} \mathrm{g}$ for $30 \mathrm{~min}$ at $4^{\circ} \mathrm{C}$. The monocytes-enriched layer was collected, plated for $2 \mathrm{~h}$ and non-adherent cells were removed with PBS. The pure monocytes were positively selected by an anti-CD14-coated microbead (MiniMACS separation column; Milteny Biotec, Inc.) as previously described (11). The cells were $>95 \%$ viable, as assessed by the Trypan blue exclusion method, and consisted of $>90 \%$ monocytes, as determined by a flow cytometry analysis. Flow cytometry $\left(\right.$ Coulter ${ }^{\circledR}$ Epics $^{\circledR}$ XL-MCL ${ }^{\mathrm{TM}}$ flow cytometer including System II $^{\mathrm{TM}}$ software; Beckman Coulter, Inc.) was based on CD14 and CD45 antigen expression after cell incubation for $30 \mathrm{~min}$ at $4^{\circ} \mathrm{C}$ in $\mathrm{PBS}$ containing 2\% FBS (Gibco ${ }^{\circledR}$; Thermo Fisher Scientific, Inc.) with mouse monoclonal anti-CD14 (phycoerythrin-cyanin 5.5; clone RMO52; IgG2a; cat. no. A70204; Beckman Coulter, Inc.) and anti-CD45 (fluorescein-5-isothiocyanate; clone 30-F11; IgG2b; cat. no. 103107; BioLegend, Inc.) antibodies (data not shown).

Cell culture and treatment. The human monocytic cell line THP-1 was obtained from the American Type Culture Collection. Both the isolated human monocytes and THP-1 cells were maintained in suspension in complete medium, composed of RPMI-1640 medium, supplemented with $10 \%$ fetal bovine serum (FBS) and 1\% antibiotics (100 IU/ml penicillin and $100 \mu \mathrm{g} / \mathrm{ml}$ streptomycin), provided by Gibco ${ }^{\circledR}$ (Thermo Fisher Scientific, Inc.). The cells were maintained in a $37^{\circ} \mathrm{C}$ humidified, $5 \% \mathrm{CO}_{2}$ incubator. The THP- 1 cells and human monocytes $\left(1 \times 10^{6} / \mathrm{ml}\right)$ were separately treated with HM (5, 10 and $50 \mu \mathrm{g} / \mathrm{ml}$ ) and lipopolysaccharides (LPS; $10 \mu \mathrm{g} / \mathrm{ml}$; E. coli, 0.26:B6; Sigma-Aldrich; Merck KGaA). Untreated THP-1 cells and monocytes were used as controls.

$R N A$ extraction and reverse transcription $(R T)-P C R$. The expression of $I L-1 \beta$ mRNA was assessed in the THP-1 cells, in the presence or absence of either HM or LPS. After 3-h incubation, the total RNA was extracted from the THP-1 cells using TRIzol reagent (Invitrogen; Thermo Fisher Scientific, Inc.), following the manufacturer's instructions. The total extract $(2 \mu \mathrm{g})$ was transcribed into a single strand cDNA in a reaction mixture $(30 \mu \mathrm{l})$ containing $1 \mathrm{X}$ reaction buffer (75 $\mathrm{mM} \mathrm{KCl,} 3 \mathrm{mM} \mathrm{MgCl}_{2}$ and $50 \mathrm{mM}$ Tris- $\mathrm{HCl} \mathrm{pH} 8.3$ ), $0.5 \mathrm{mM}$ deoxynucleoside triphosphate mixture, $1.5 \mathrm{mM}$ oligo(dT)primer, $1 \mathrm{U}$ RNasin and $10 \mathrm{U}$ Moloney murine leukemia virus reverse transcriptase (Clontech Laboratories, Inc.), as described previously (10). Amplification of the $I L-1 \beta$ cDNA, along with the amplification of $\beta$-actin cDNA (used as a housekeeping gene), was performed on a ThermoHybrid thermocycler (Thermo Fisher Scientific, Inc.) using Taq DNA polymerase (Roche Molecular Diagnostics) and the following PCR primers (Invitrogen; Thermo Fisher Scientific, Inc.): $I L-1 \beta$ sense, 5'-AAACAGATGAAGTGCTCCTTCCAGG-3' and antisense, 5'-TGGAGAACACCACTTGTTGCTCCA-3'; and $\beta$-actin sense, 5'-ATCTGGCACCACACCTTCTACAATGAG CTGCG-3' and antisense, 5'-CGTCATACTCCTGCTTGC TGATCCACATCTGC-3'. The PCR thermocycling conditions for $I L-1 \beta$ cDNA amplification consisted if an initialization step for $10 \mathrm{~min}$ at $95^{\circ} \mathrm{C}$, followed by 30 cycles of denaturation at $94^{\circ} \mathrm{C}$ for $30 \mathrm{sec}$, annealing at $65^{\circ} \mathrm{C}$ for $1 \mathrm{~min}$ and extension at $72^{\circ} \mathrm{C}$ for $2 \mathrm{~min}$, while the PCR conditions for $\beta$-actin cDNA amplification consisted of an initialization step for $10 \mathrm{~min}$ at $95^{\circ} \mathrm{C}$, followed by 40 cycles of denaturation at $94^{\circ} \mathrm{C}$ for $45 \mathrm{sec}$, annealing at $61^{\circ} \mathrm{C}$ for $45 \mathrm{sec}$ and extension at $72^{\circ} \mathrm{C}$ for $2 \mathrm{~min}$. The cDNA products were separated on $2 \%$ agarose gel with electrophoresis, and visualized through ethidium bromide staining.

Enzyme-linked immunosorbent assay (ELISA). The THP-1 cells and isolated monocytes $\left(1 \times 10^{6} / \mathrm{ml}\right)$ were treated with different concentrations of HM or LPS at $10 \mu \mathrm{g} / \mathrm{ml}$, for various incubation times (1, 3, 6 and $24 \mathrm{~h})$. The cell-free supernatants were recovered through centrifugation at $10,000 \mathrm{x}$ g for $10 \mathrm{~min}$ at $4^{\circ} \mathrm{C}$ and stored at $-20^{\circ} \mathrm{C}$ until assayed. Complete medium was used as a negative control. The concentration of IL-1 $\beta$ was determined using an IL-1 $\beta$ ELISA kit (cat. no. HSLB00D; 
R\&D Systems, Inc.), following the manufacturer's instructions. To verify that the HM did not interfere with the measurements, an additional control was obtained by incubating $100 \mu \mathrm{g} / \mathrm{ml}$ $\mathrm{HM}$ in complete medium for $24 \mathrm{~h}$ at $37^{\circ} \mathrm{C}$. Of note, repeated assays showed that the HM solution did not affect the cytokine measurements (data not shown). The sensitivity of the assay for IL-1 $\beta$ detection was $>4 \mathrm{pg} / \mathrm{ml}$.

Protein extraction and western blotting analysis. The THP-1 cells $\left(1 \times 10^{6} / \mathrm{ml}\right)$ were seeded in a 24 -well plate $\left(\mathrm{Nunc}^{\mathrm{TM}}\right)$, in $0.5 \mathrm{ml}$ complete medium. The untreated cells (control) and cells treated with $10 \mu \mathrm{g} / \mathrm{ml}$ of HM or LPS were incubated for 1,6 and $24 \mathrm{~h}$. After each incubation period, the medium was discarded, and each well was rinsed with $500 \mu \mathrm{l}$ cold PBS. Then, ice-cold NP40 lysis buffer ( $80 \mu \mathrm{l}$; Invitrogen; Thermo Fisher Scientific, Inc.) were added to the wells and the plate was kept on ice and shaken gently for $25 \mathrm{~min}$. The proteins were extracted from the fully lysed cells and protein concentration was estimated using the fluorescence-based Qubit ${ }^{\mathrm{TM}}$ Protein quantitation assay kit (Thermo Fisher Scientific, Inc.). The cell lysate preparation, protein separation by $12 \%$ SDS-PAGE, and the transfer of the separated proteins to polyvinylidene difluoride (PVDF) membranes (EMD Millipore) were performed as previously described (26). The PVDF membranes (Thermo Fisher Scientific, Inc.) were stained with primary antibodies diluted $(1: 1,000)$ in TBS- $0.1 \%$ Tween- 20 containing $1 \%$ BSA (Thermo Fisher Scientific, Inc.), overnight at $4^{\circ} \mathrm{C}$ on a rotating shaker. The primary antibodies included mouse monoclonal [T2.5] anti-TLR2 antibody (cat. no. ab16894), rabbit polyclonal anti-TLR4 antibody (cat. no. ab13867), mouse monoclonal [OTI3E1] anti-IL-1 $\beta$ antibody (cat. no. ab156791), rabbit monoclonal anti-phospho-p38 (Y182) antibody (cat. no. ab47363), mouse monoclonal [M138] anti-total-p38 antibody (cat. no. ab31828) and mouse monoclonal [6C5] anti-GAPDH antibody (cat. no. ab8245), all from Abcam. The primary antibodies were detected with an infrared fluorescent IRDye ${ }^{\circledR}$ 680RD (red)-conjugated goat anti-rabbit (cat. no. 926-68071) or IRDye ${ }^{\circledR}$ 800RD (green)-conjugated goat anti-mouse secondary antibody (cat. no. 926-32210) (both LI-COR Biosciences) diluted in TBS-0.1\% Tween-20 containing $3 \%$ BSA $(1: 5,000)$ for $1 \mathrm{~h}$ at room temperature with continuous shaking. After five additional washes in TBS- $0.1 \%$ Tween-20, the proteins were visualized using the LI-COR Odyssey CLx Scanner (LI-COR Biosciences) and analyzed using ImageJ software v.1.46r (http://rsbweb.nih. gov/ij/index.html).

TLR neutralization and p38 MAPK pathway blockade. To investigate whether the HM-induced IL-1 $\beta$ production functions through the TLR and p38 MAPK pathway, the cells were treated with anti-TLR2 (cat. no. ab16894) and anti-TLR4 (cat. no. ab13867) antibodies (both Abcam), or the p38 MAPK pharmacological inhibitor SB202190 (cat no. sc-222294; Santa Cruz Biotechnology, Inc.) to neutralize the TLR receptors and block the p38 MAPK pathway. Briefly, the THP-1 cells $\left(1 \times 10^{6} / \mathrm{ml}\right)$ were seeded in complete medium in each well of a 24 -well plate. The medium was renewed with $20 \mu \mathrm{g} / \mathrm{ml}$ mouse monoclonal anti-TLR2 or polyclonal anti-TLR4 antibodies (concentration fixed from pilot studies), and $20 \mu \mathrm{g} / \mathrm{ml} \mathrm{IgG}_{1}$ was used as an isotype control or the medium was renewed with

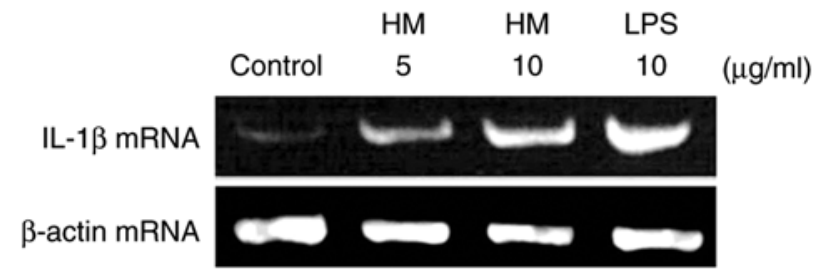

Figure 1. Stimulatory effects of HM and LPS on IL-1 $\beta$ mRNA expression in THP-1 cells. Representative electrophoresis gel showing the effects of increasing concentrations of HM $(5-10 \mu \mathrm{g} / \mathrm{ml}$. along with LPS $(10 \mu \mathrm{g} / \mathrm{ml}$. on the THP-1 cells, resulting in increased levels of IL-1 $\beta$ mRNA compared with the untreated cells after $3 \mathrm{~h}$ of incubation. $\beta$-actin mRNA was used as an internal loading control. HM, herbal melanin; LPS, lipopolysaccharide; IL-1 $\beta$, interleukin-1 $\beta$.

$20 \mu \mathrm{M}$ SB202190 or with DMSO, used as a negative control. After $2 \mathrm{~h}$ of incubation, the cells were treated with either $10 \mu \mathrm{g} / \mathrm{ml}$ of $\mathrm{HM}$ or LPS for $1 \mathrm{~h}$ stimulation at $37^{\circ} \mathrm{C}$, followed by protein extraction for western blotting.

Statistical analysis. All the experimental data are expressed as means + standard deviation (SD). A generalized linear mixed model (GLMM) procedure from SAS system software (version 9.2; SAS Institute Inc.) was used to compare the protein expression level between and within each treatment at different exposure times. Pairwise comparisons were performed using Tukey's studentized range (HSD) post hoc test. $\mathrm{P}<0.05$ was considered to indicate a statistically significant difference.

\section{Results}

Herbal melanin (HM) increases monocytic IL-1 $\beta$ gene expression and secretion from THP-1 cells and isolated human monocytes. IL-1 $\beta$ gene expression was monitored by the mRNA expression level, analyzed by RT-PCR after extraction of the total RNA from the cultured human THP-1 cells incubated with and without HM (5 and $10 \mu \mathrm{g} / \mathrm{ml})$ and LPS $(10 \mu \mathrm{g} / \mathrm{ml})$ for $3 \mathrm{~h}$. As shown in Fig. 1, the untreated THP-1 cells (the control) expressed very low levels of IL-1 $\beta$ mRNA, which was concomitantly induced in response to LPS $(10 \mu \mathrm{g} / \mathrm{ml})$. The addition of different concentrations of HM (5 and $10 \mu \mathrm{g} / \mathrm{ml}$ ) increased the IL-1 $\beta$ mRNA expression level in a dose-dependent manner compared with the basal level of IL-1 $\beta$ mRNA expression detected in the untreated THP-1 cells (Fig. 1). Using ELISA, very low levels of IL-1 $\beta$ protein were detected in the supernatant of the primary culture of untreated monocytes, with a mean of $1.9 \mathrm{pg} / \mathrm{ml}$ (Fig. 2A). Both the LPS $(10 \mu \mathrm{g} / \mathrm{ml})$ and $\mathrm{HM}(5$ and $10 \mu \mathrm{g} / \mathrm{ml})$ significantly enhanced IL-1 $\beta$ secretion from the monocytes compared with the primary culture of the untreated monocytes (Fig. $2 \mathrm{~A} ; \mathrm{P}<0.01$ ). Using equal concentrations of HM and LPS $(10 \mu \mathrm{g} / \mathrm{ml})$, the HM was more effective in inducing the IL-1 $\beta$ secretion compared with LPS (215.6 and $81.5 \mathrm{pg} / \mathrm{ml}$, respectively; Fig. 2A). Fig. 2B displays detectable amounts of the IL- $1 \beta$ protein in the supernatants of the untreated THP-1 cells $(24.5 \mathrm{pg} / \mathrm{ml})$. Both the LPS and HM significantly induced IL- $1 \beta$ secretion (reaching $\sim 400 \mathrm{pg} / \mathrm{ml}$ ) from the THP-1 cells, when tested at $10 \mu \mathrm{g} / \mathrm{ml}$ $(\mathrm{P}<0.0001$; Fig. 2B). The THP-1 cell treatment with $50 \mu \mathrm{g} / \mathrm{ml}$ $\mathrm{HM}$, resulted in the highest stimulatory effect on IL-1 $\beta$ secretion, (mean, $6037.7 \mathrm{pg} / \mathrm{ml} ; \mathrm{P}<0.0001$; Fig. 2B). At the incubation 
A

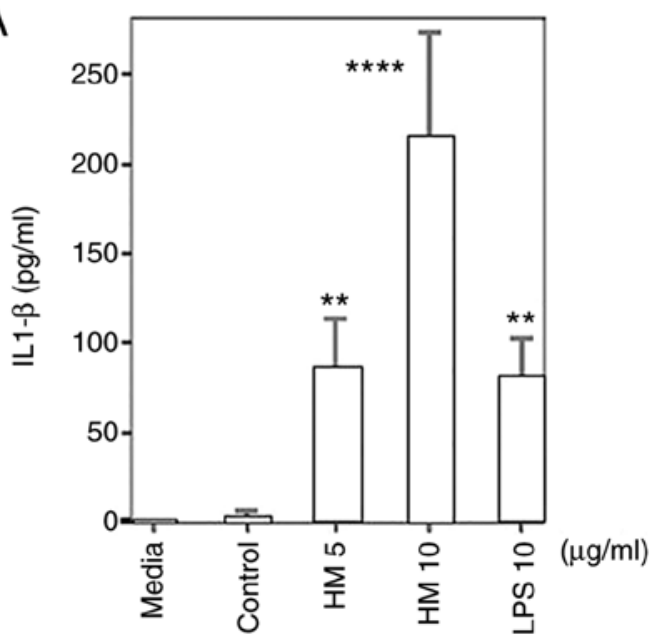

B

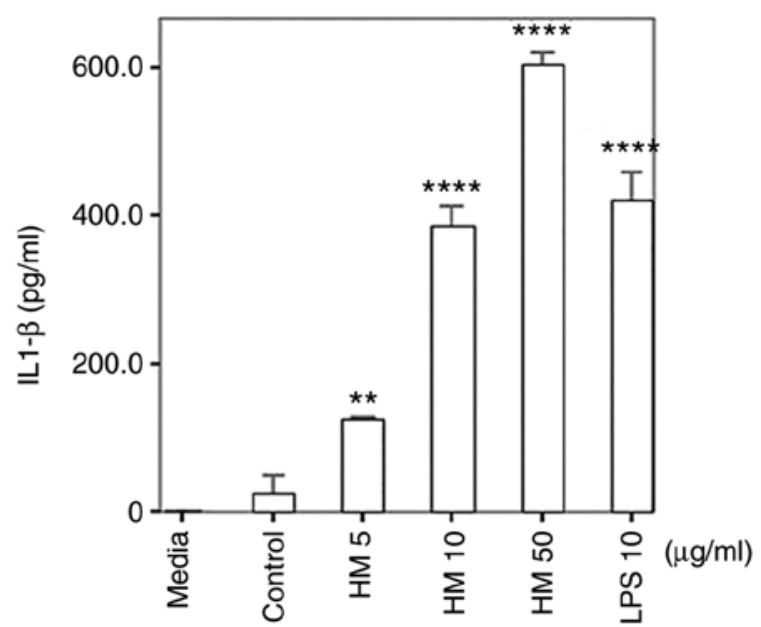

Figure 2. Effect of HM on IL-1 $\beta$ secretion by (A) human monocytes and (B) THP-1 cells. Bar graph shows IL-1 $\beta$ secretion evaluated in the supernatant of isolated monocytes and cultured THP-1 cells using enzyme-linked immunosorbent assay kit after $3 \mathrm{~h}$ of incubation. The results are presented as the mean \pm SD of three independent experiments. ${ }^{* *} \mathrm{P}<0.01$ and ${ }^{* * * *} \mathrm{P}<0.0001$ vs. control, the untreated cells. HM, herbal melanin; LPS, lipopolysaccharide; IL-1 $\beta$, interleukin-1 $\beta$.

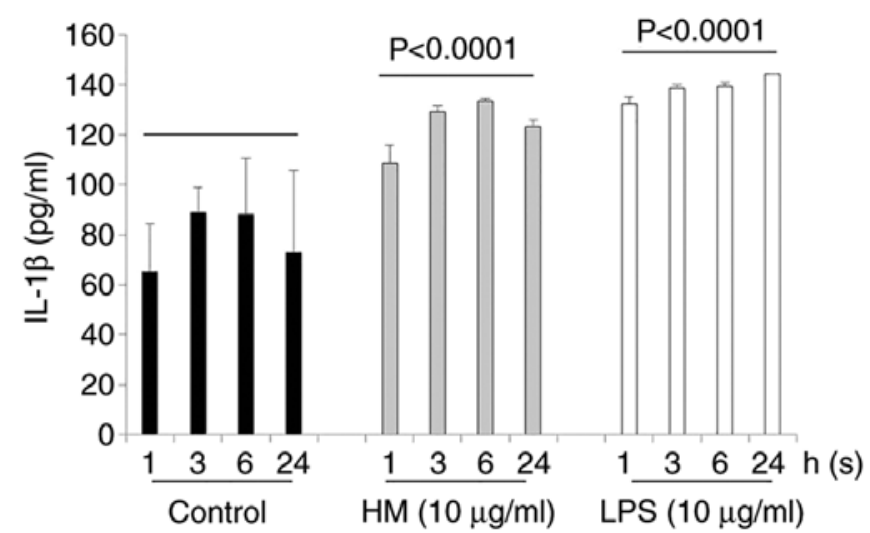

Figure 3. Effect of HM on IL-1 $\beta$ secretion by THP-1 cell line. Bar graph shows the time course of IL- $1 \beta$ secretion detected in the supernatant of cultured THP-1 cells using the enzyme-linked immunosorbent assay kit. The results are presented as the mean \pm SD of three independent experiments. Statistically significant difference $(\mathrm{P}<0.0001$. was determined compared with the control group. HM, herbal melanin; LPS, lipopolysaccharide; IL-1 $\beta$, interleukin-1 $\beta$.

time points (1, 3, 6 and $24 \mathrm{~h})$, both the HM and LPS increased IL-1 $\beta$ secretion by the THP-1 cells in a time-dependent manner compared with the untreated cells (Fig. 3). As previously observed, when using equal concentrations $(10 \mu \mathrm{g} / \mathrm{ml})$, the HM was as effective as the LPS in inducing IL-1 $\beta$ secretion by the THP- 1 cells, after 3 and even $6 \mathrm{~h}$ of incubation (Fig. 3). After $24 \mathrm{~h}$ of THP-1 cell treatment, a decrease in IL-1 $\beta$ secretion was detected in the supernatant of HM-treated THP- 1 cells compared with the quantity of IL- $1 \beta$ released by the LPS-treated THP-1 cells (Fig. 3).

HM modulates IL-1 $\beta, T L R 4$ and TLR2 protein expression in THP-1 cells. Western blot analysis revealed that the IL-1 $\beta$ protein expression level in the untreated THP-1 cells fluctuated over time (1, 6 and $24 \mathrm{~h})$, with a peak expression after $6 \mathrm{~h}$ incubation compared with the IL-1 $\beta$ basal level detected in the untreated cells after 1-h incubation (Fig. 4A). Both the
$10 \mu \mathrm{g} / \mathrm{ml} \mathrm{HM}$ and LPS significantly $(\mathrm{P}<0.01)$ increased IL-1 $\beta$ protein expression at the 6 -h incubation with $\mathrm{HM}$, and at 1-h incubation with LPS (Fig. 4B). No significant difference in the IL-1 $\beta$ expression levels was detected in the HM- and LPS-treated cells between 6 and $24 \mathrm{~h}$ of incubation (Fig. 4).

As the main receptor for HM (11), a time course of the TLR4 protein expression was assessed in $10 \mu \mathrm{g} / \mathrm{ml} \mathrm{HM-} \mathrm{and}$ LPS-treated THP-1 cells. In addition, as the TLR2 is mostly involved in LPS-induced IL- $1 \beta$ production and secretion by THP-1 cells (27), the time course of the TLR2 protein expression was also monitored. In the untreated cells, significant increases in the TLR4 and TLR2 protein expression were observed at 6 and $24 \mathrm{~h}$ od incubation compared to the basal level of the TLR4 and TLR2 expression detected in the untreated cells after $1 \mathrm{~h}$ incubation (Fig. 4; $\mathrm{P}<0.05$ ). The addition of HM induced a significant increase in TLR4 (2.2-fold; $\mathrm{P}<0.01)$ at all incubation times, and the TLR2 expression increased by 2.51 -fold $(\mathrm{P}<0.01)$ at $6 \mathrm{~h}$ incubation, followed by a decrease at $24 \mathrm{~h}$ incubation, reaching a level of expression similar to the level detected in the HM-treated cells after $1 \mathrm{~h}$ of incubation (Fig. 4). The THP-1 cell treatment with LPS resulted in a higher increase in both the TLR4 $(\mathrm{P}<0.0001)$ and TLR2 $(\mathrm{P}<0.001)$ expression levels by 2.41 - and 2.52 -folds after 1-h incubation and by 3.3- and 4.5-fold after 6-24 h incubation compared with the basal level of the TLR4 and TLR2 protein expression detected in untreated cells, after $1 \mathrm{~h}$ incubation, respectively (Fig. 4).

HM induces the phosphorylation of p38 MAPK in THP-1 cells. Different studies reported that the activation of the TLR4 and TLR2 by LPS activates the MAPK signaling pathways, including the p38 MAPK, which subsequently results in IL-1 $\beta$ production $(28,29)$. Over the time $(1,6$ and $24 \mathrm{~h})$, the LPS and HM similarly increased the protein expression levels of phospho-p38 in THP-1 cells with a peak p38 phosphorylation level reached at 6-h incubation compared with the basal phopsho-p38 expression level detected in untreated cells after 1-h incubation (Fig. 5). 
A

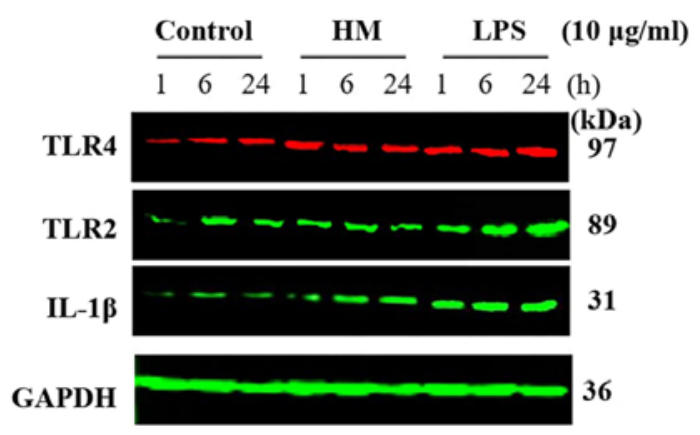

B

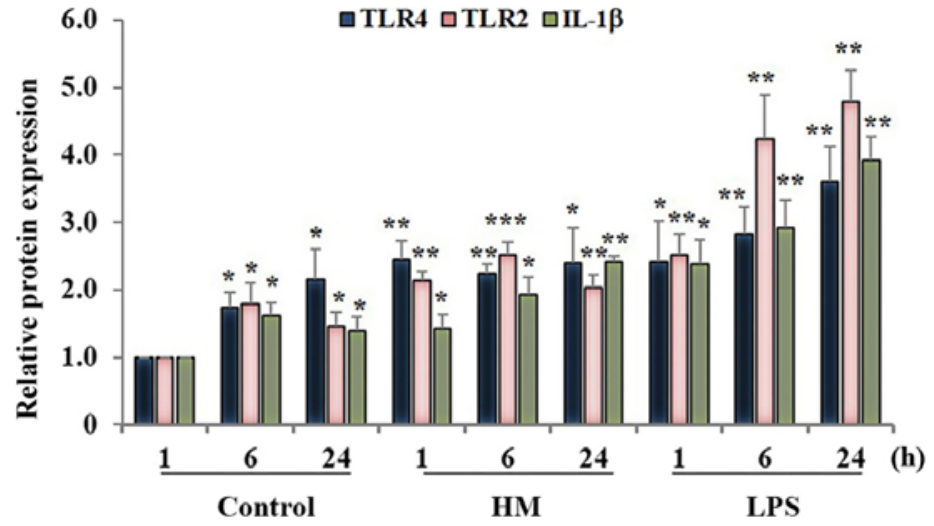

Figure 4. Effect of HM on TLR2, TLR4 and IL-1 $\beta$ protein expression. Representative western blot analysis (A) showing the effect of HM and LPS (10 $\mu \mathrm{g}$ ml. on TLR2 protein expression in THP-1 cells after various incubation time points ( 1,6 and $24 \mathrm{~h}$. compared with the untreated cells, the control group. The bar graph (B) shows the relative protein expression levels of TLR2 calculated as a ratio of GAPDH expression (the loading control). The results are presented as the mean $\pm \mathrm{SD}$ of three independent experiments. ${ }^{*} \mathrm{P}<0.05,{ }^{* *} \mathrm{P}<0.01$ and ${ }^{* * * *} \mathrm{P}<0.001$ vs. control at $1 \mathrm{~h}$. HM, herbal melanin; TLR, Toll-like receptor; LPS, lipopolysaccharide; IL-1 $\beta$, interleukin-1 $\beta$.

A

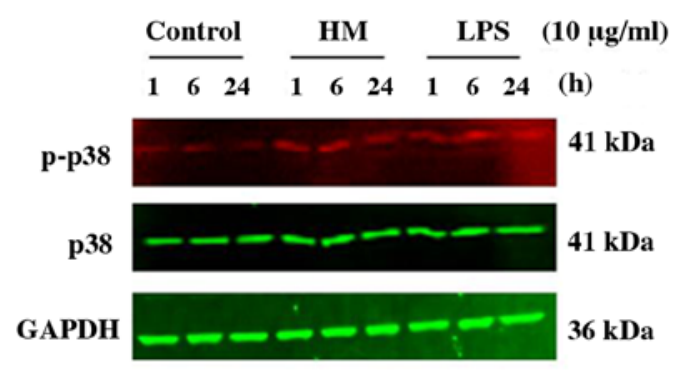

B

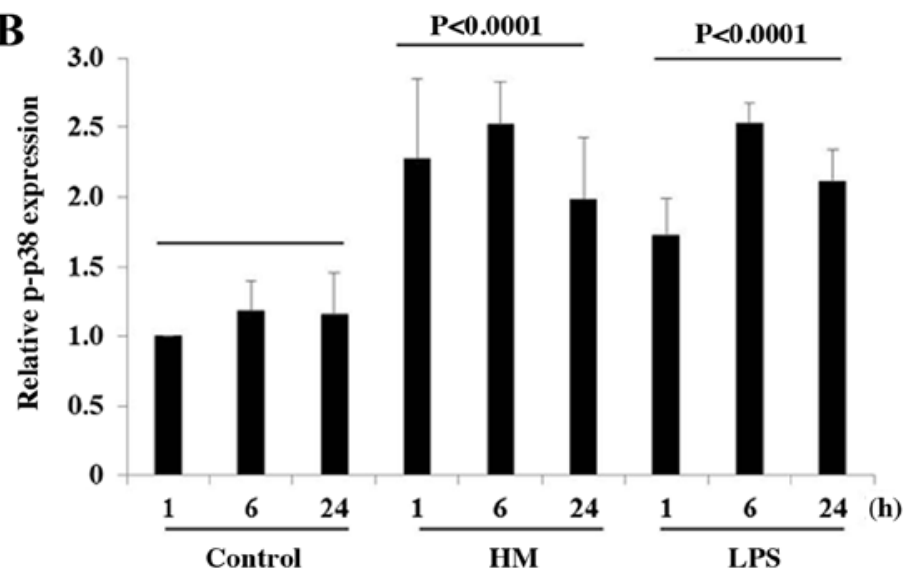

Figure 5. Effect of HM on the phosphorylation of p38 MAPK. Representative western blotting. (A) showing the effect of HM and LPS (10 $\mu \mathrm{g} / \mathrm{ml}$. on p38 MAPK phosphorylation in THP-1 cells after 1-, 6- and 24-h stimulation compared with the untreated cells. The bar graph. (B) shows the relative protein expression levels of p-p38 calculated as a ratio of total p38 expression (the loading control). The results are presented as the mean \pm SD of three independent experiments. P-values signify a statistically significant difference compared with the control group. HM, herbal melanin; LPS, lipopolysaccharide; IL-1 $\beta$, interleukin-1 $\beta$; p-, phosphorylated.

HM mainly requires TLR2 and p38 MAPK pathway activation forIL-1 $\beta$ production. Todemonstrate the requirement of theTLR2, TLR4 and $\mathrm{p} 38$ MAPK pathway in HM-induced IL-1 $\beta$ production, specific inhibitors, anti-TLR2, anti-TLR4 neutralizing antibodies and p38 MAPK pharmacological inhibitor SB202190, were added to the cells before cell exposure to $10 \mu \mathrm{g} / \mathrm{ml} \mathrm{HM}$ or LPS for 1-h treatment. Optimization of the respective concentrations of the anti-TLR2, anti-TLR4 antibodies and SB202190 p38 MAPK pharmacological inhibitor, were based on preliminary studies (data not shown). The blockade of the p38 MAPK pathway resulted in a quasi-disappearance of the p38 phosphorylation, detected in the untreated and HM-treated cells, and a slight phosphorylation was still detected in the LPS-treated THP-1 cells (Fig. 6A). The TLR4 receptor blockade did not completely inhibit the HM- and LPS-induced p38 phosphorylation (Fig. 6A). In terms of the impact of the TLR2/4 and p38 MAPK pathway blockade on the HM-induced IL- $1 \beta$ production, both the TLR2 receptor neutralization and SB202190 pharmacological inhibitor highly suppressed the HM stimulatory effect on the IL-1 $\beta$ protein expression and, to a lesser extent, the LPS stimulatory effect (Fig. 6B and C). However, the TLR4 receptor blockade had a minor effect on the HM-induced IL-1 $\beta$ expression in THP-1 cells (Fig. 6B).

\section{Discussion}

The immunogenic properties of the HM extract from Nigella sativa seeds have been reported, based on the production and secretion of pro-inflammatory cytokines, such as IL-6, TNF- $\alpha$ and VEGF, due to TLR4 activation and the $\mathrm{NF}-\kappa \mathrm{B}$ signaling pathway (10-12). However, no study reported the immunoregulatory potential of HM through the pro- and anti-inflammatory cytokine IL- $1 \beta$ produced by human monocytes and macrophages. In the current study, the effect of HM was tested on the monocytic cell line THP-1, with isolated human monocytes from healthy donors. The immunoregulatory potential of HM was tested in parallel with LPS, used as a bacterial stimulatory agent, based on the level of IL-1 $\beta$ 
A

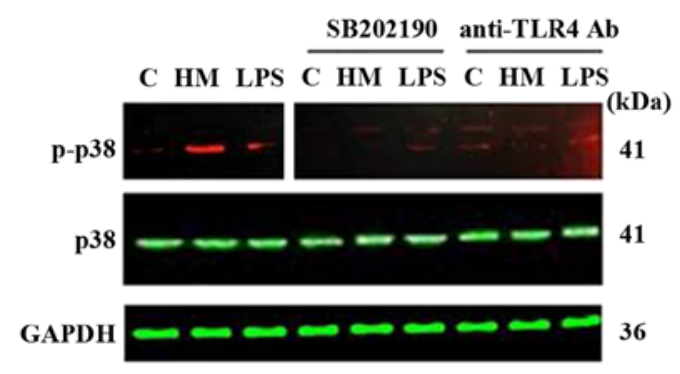

B

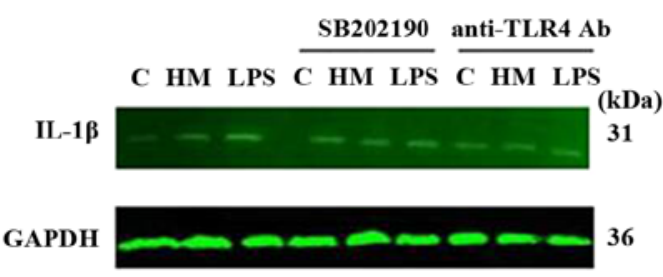

C

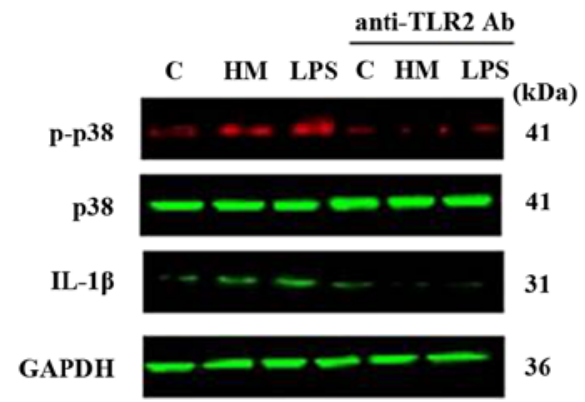

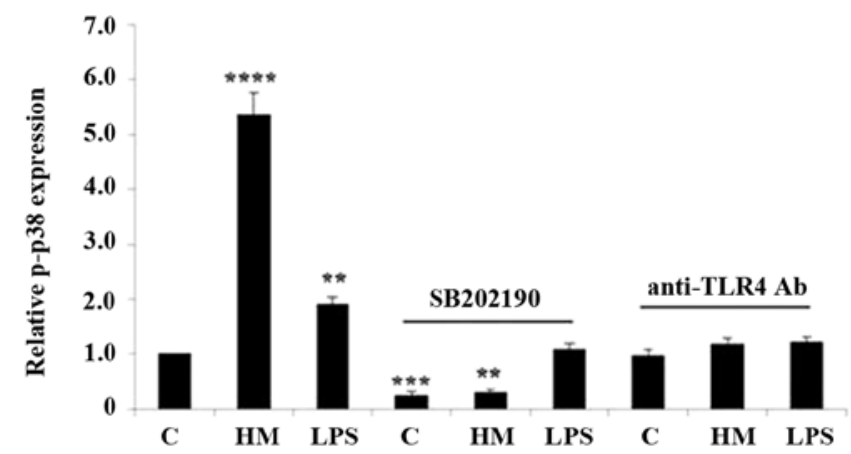
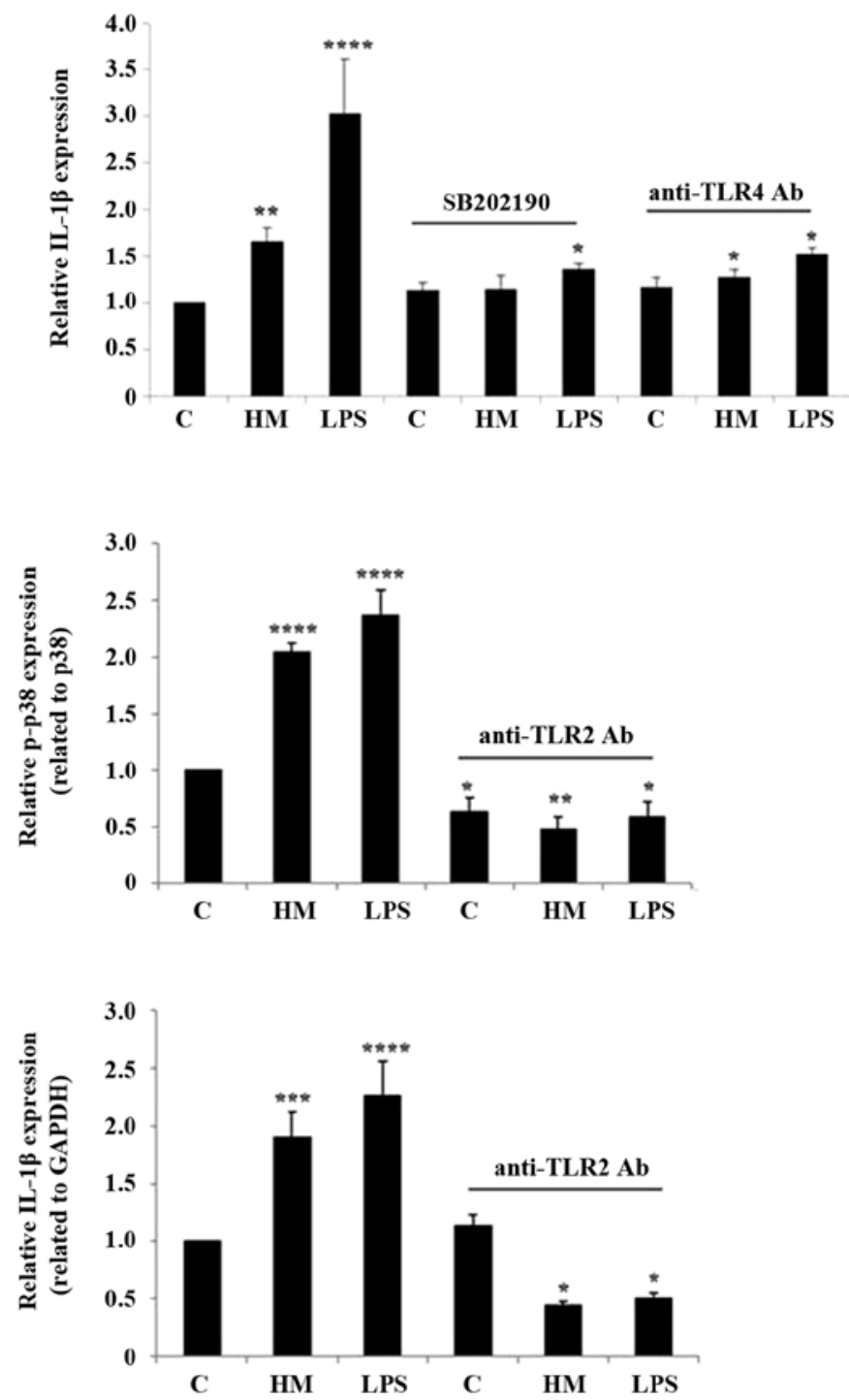

Figure 6. Impact of TLR2, TLR4 receptor neutralization and of the p38 MAPK pathway pharmacological inhibitor SB202190 on HM-induced p38 phosphorylation and IL-1 $\beta$ protein expression. Representative western blot analysis showing the impact of p38 MAPK pharmacological inhibitor SB202190 and TLR4 blockade using anti-TLR4 Ab on HM and LPS-induced. (A) p38 MAPK phosphorylation and (B) IL-1 $\beta$ expression in THP-1 cells after 1-h stimulation compared with the untreated cells, the control. (C) Representative western blotting showing the impact of TLR2 blockade using anti-TLR2 Ab on HM and LPS-induced p38 MAPK phosphorylation and IL-1 $\beta$ expression in the THP-1 cells after 1-h stimulation compared with the untreated cells, the control. The bar graphs show the relative protein expression levels of (A and C) p-p38 and (B and C) IL-1 $\beta$ calculated as a ratio of either total p38 expression or GAPDH (the loading controls). The results are presented as the mean $\pm \mathrm{SD}$ of three separate experiments. ${ }^{*} \mathrm{P}<0.05,{ }^{* * *} \mathrm{P}<0.01,{ }^{* * * *} \mathrm{P}<0.001$ and ${ }^{* * * *} \mathrm{P}<0.0001$ vs. control. TLR, Toll-like receptor; HM, herbal melanin; C, control; LPS, lipopolysaccharide; IL-1 $\beta$, interleukin-1 $\beta$; Ab, antibody; p-, phosphorylated.

production and secretion from the primary culture of human monocytes and THP-1 cells. It was demonstrated that the HM upregulated the IL-1 $\beta$ gene expression in the THP-1 cells, and induced the secretion of IL-1 $\beta$ from isolated monocytes and cultured THP-1 cells compared with the untreated cells. In addition, HM increased the protein expression of IL-1 $\beta$, TLR2 
but not TLR4, and enhanced $\mathrm{p} 38$ MAPK phosphorylation in the THP-1 cells. The blockade of the p38 MAPK pathway and the TLR2 receptor decreased the HM-induced IL-1 $\beta$ upregulation in the THP-1 cells. The TLR4 receptor blockade also decreased HM-induced IL-1 $\beta$ expression, but to a lesser extent than the TLR2 blockade. In conclusion, it was demonstrated that the $\mathrm{HM}$ mainly induces IL-1 $\beta$ production by the monocytic cell line THP-1, in a TLR2/p38 MAPK pathway-dependent manner. These findings suggest the potential immunoregulation of the HM through the IL-1 $\beta$ is possibly of interest for the treatment of inflammatory-related diseases.

The present study was conducted in vitro, using the human monocytic cell line THP-1 and isolated monocytes, as they represent the main source of cytokines including IL-1 $\beta$. The IL-1 $\beta$ gene is tightly regulated by positive and negative regulatory elements in monocytes and macrophages (30). LPS is the best-characterized stimulant that triggers IL-1 $\beta$ transcription and its release $(31,32)$. Consequently, in the present study with the HM, LPS was used as a positive stimulant for promoting IL-1 $\beta$ production in human monocytes and monocytic THP-1 cells $(33,34)$. Using a RT-PCR, ELISA and western blotting, it was found that HM increased the IL-1 $\beta$ mRNA expression level, secretion, and production of the protein by the THP-1 cells and isolated monocytes. The effects of Nigella sativa total extracts or melanins, other than Nigella sativa melanin on IL-1 $\beta$ production were independently studied by various groups. Haq et al (7) reported that the whole Nigella sativa protein extract, containing a number of proteins ranging from $94 \mathrm{Da}$ to $10 \mathrm{kDa}$, induced IL-1 $\beta$ in PBMC. However, literature associated with the effect of melanin on IL-1 $\beta$ production are contradictory. Pugh et al (6) demonstrated that Echinacea melanin increased the production of IL-1 $\beta$ in THP-1 cells, but Mohagheghpour et al (35) reported an inhibitory effect of the synthetic melanin on IL-1 $\beta$ production. The present results regarding LPS/IL- $1 \beta$ production by the THP-1 cells supported the results of Jablonska and Marcinczyk (27), indicating that LPS increased IL-1 $\beta$ production in THP-1 cells through TLR2 activation.

Due to the important role of TLR2 in IL-1 $\beta$ production in monocytes and THP-1 cells, the protein expression levels of TLR2 and TLR4, described as the main receptor for HM, were monitored. The addition of $10 \mu \mathrm{g} / \mathrm{ml} \mathrm{HM}$ or LPS increased the TLR2 receptor, but no change in the TLR4 protein expression was observed in the THP-1 cells. Literature demonstrated that a high concentration of LPS upregulated both TLR4 and TLR2 in macrophages, through the activation of the NF- $\mathrm{B}$ pathway $(36,37)$. In addition, it was recently reported that a high concentration of HM upregulated the TLR4 gene and protein expression in THP-1 cells (38). Using an anti-inflammatory peptide, such as the vasoactive intestinal peptide, LPS tested at $100 \mathrm{ng} / \mathrm{ml}$ increased the TLR 2 gene expression in THP-1 cells after the stimulation of the NF- $\mathrm{BB}$ and activator protein (AP) 1 transcription factors (39). After reporting that HM induces the NF-kB pathway activation in THP-1 cells, an assessment of the $\mathrm{NF}-\kappa \mathrm{B}$ and AP1 transcription factors could confirm the TLR2 gene upregulation in HM-treated THP-1 cells.

In addition to the NF-kB pathway and the MAPK activated members stimulated by LPS, the p38 MAPK is primarily involved in LPS-induced IL-1 $\beta$ production in THP-1 cells $(25,40)$. In the present study, it was reported that both HM and LPS enhanced p38 MAPK phosphorylation in the THP-1 cells. Zheng et al (25) reported the important role of the p38 MAPK in IL- $1 \beta$ transcription by acting through the $\mathrm{C} / \mathrm{EBP} / \mathrm{NFIL}-6$ transcription factors. A blockade of the p38 MAPK pathway in the HM-treated THP-1 cells could result in the decrease in IL- $1 \beta$ gene expression, and the inactivation of C/EBP/NFIL- 6 transcription factors.

To expose the key role of the TLR2, TLR4 and the p38 MAPK pathway in HM-induced IL- $1 \beta$ production, respective receptors were neutralized with antibodies, and the p38 MAPK was blocked with a specific pharmacological inhibitor. It was shown that the blockade of the p38 MAPK pathway and the TLR2 receptor decreased HM-induced IL- $1 \beta$ production in THP-1 cells. The TLR4 receptor blockade also decreased the HM-induced IL-1 $\beta$ expression, but to a lesser extent compared with the TLR 2 blockade. The detection of the IL- $1 \beta$ protein following the TLR4 receptor blockade could be attributed to the partial inhibitory effect observed on the HM- and LPS-induced p38 MAPK phosphorylation and to the IL-1 $\beta$ protein secreted via TLR2 activation. The blockade of the TLR2 or TLR4 receptor resulted in the inhibition of the p38 MAPK phosphorylation, confirming subsequent shared downstream signaling pathways, such as the IL-1 receptor associated kinase (IRAK)/tumor necrosis factor receptor-associated factor 6/transforming growth factor $\beta$-activated kinase, reported in the literature $(41,42)$.

In conclusion, the present study provides evidence that $\mathrm{HM}$ induces IL-1 $\beta$ production by human monocytes and THP-1 cells expressing TLR2 and TLR4. Furthermore, HM upregulates TLR2 and TLR4, and activates the p38 MAPK pathway. TLR2 blockade completely inhibited HM-induced IL- $1 \beta$ production, and the TLR4 blockade had a partially inhibitory effect. Overall, it is proposed that HM has efficiently induced IL-1 $\beta$ production, primarily via the activation of the TLR2/p38 MAPK signaling pathway. Future identification of the signaling molecules involved in the observed HM stimulatory effect of IL-1 $\beta$ production in monocytes, may assist in the development of novel therapeutics to enhance or downregulate the IL-1 $\beta$ signaling pathways in response to infections and other inflammatory-associated diseases.

\section{Acknowledgements}

The authors would like to thank Ms. Nouf AlGaith from Cell and Gene Therapy Group, King Abdullah International Medical Research Center (Riyadh, Saudi Arabia), for her technical assistance.

\section{Funding}

The experiments using THP-1 cells were financially supported by King Abdullah International Medical Research Center (grant no. \#RC15/106).

\section{Availability of data and materials}

The datasets used and/or analyzed during the current study are available from the corresponding author on reasonable request.

\section{Authors' contributions}

AEO and SMN conceived the study. WBY, BA, AAT, MN, $\mathrm{AH}$ performed the assays, collected the data, conducted the 
data analysis, and reviewed the manuscript. SMN and AEO wrote the manuscript. AEO and SMN confirm the authenticity of all the raw data. All authors read and approved the final version of the manuscript.

\section{Ethics approval and consent to participate}

Healthy control subject's blood samples were processed by Dr Adila El-Obeid while she was affiliated with the Department of Genetics and Pathology, Rudbeck Laboratory, Uppsala University Hospital, Uppsala, Sweden, in 2005. The study was approved by the institutional review board of Uppsala University hospital and conducted in accordance with the Helsinki Declaration of 1975 . Written informed consents were obtained from all healthy control subjects.

\section{Patient consent for publication}

Not applicable.

\section{Competing interests}

The authors declare that they have no competing interests.

\section{References}

1. Prota G: Regulatory mechanisms of melanogenesis: Beyond the tyrosinase concept. J Invest Dermatol 100 (Suppl 2): 156S-161S, 1993.

2. Riley P: Molecules in focus: Melanin. Int J Biochem Cell Biol 29: 1235-1239, 1997.

3. Bell AA: Biochemical mechanisms of disease resistance. Ann Rev Plant Physiol 32: 21-81, 1981.

4. Rosas ÁL, MacGill RS, Nosanchuk JD, Kozel TR and Casadevall A: Activation of the alternative complement pathway by fungal melanins. Clin Diagn Lab Immunol 9: 144-148, 2002.

5. Freitak D, Vanatoa A, Ots I and Rantala MJ: Formation of melanin-based wing patterns is influenced by condition and immune challenge in Pieris brassicae. Entomol Exp et Applicata 116: 237-243, 2005.

6. Pugh ND, Balachandran P, Lata H, Dayan FE, Joshi V, Bedir E, Makino T, Moraes R, Khan I and Pasco DS: Melanin: Dietary mucosal immune modulator from Echinacea and other botanical supplements. Int Immunopharmacol 5: 637-647, 2005.

7. Haq A, Lobo PI, Al-Tufail M, Rama NR and Al-Sedairy ST: Immunomodulatory effect of Nigella sativa proteins fractionated by ion exchange chromatography. Int J Immunopharmacol 21: 283-295, 1999.

8. Islam SN, Begum $\mathrm{P}$, Ahsan $\mathrm{T}$, Huque $\mathrm{S}$ and Ahsan $\mathrm{M}$ : Immunosuppressive and cytotoxic properties of Nigella sativa. Phytother Res 18: 395-398, 2004.

9. Hassib A: Extraction of melanin from Nigella sativa L. Patent no. 451. Khartoum, Sudan, 1998

10. El-Obeid A, Al-Harbi S, Al-Jomah N and Hassib A: Herbal melanin modulates tumor necrosis factor alpha (TNF-alpha), interleukin 6 (IL-6. and vascular endothelial growth factor (VEGF). production. Phytomedicine 13: 324-333, 2006.

11. El-Obeid A, Hassib A, Pontén F and Westermark B: Effect of herbal melanin on IL-8: A possible role of Toll-like receptor 4 (TLR4). Biochem Biophys Res Commun 344: 1200-1206, 2006.

12. Oberg F, Haseeb A, Ahnfelt M, Pontén F, Westermark B and El-Obeid A: Herbal melanin activates TLR4/NF-kappaB signaling pathway. Phytomedicine 16: 477-484, 2009.

13. Madej MP, Töpfer E, Boraschi D and Italiani P: Different regulation of interleukin-1 production and activity in monocytes and macrophages: Innate memory as an endogenous mechanism of IL-1 inhibition. Front Pharmacol 8: 335, 2017.

14. Dinarello CA: Overview of the IL-1 family in innate inflammation and acquired immunity. Immunol Rev 281: 8-27, 2018.
15. Semino C, Carta S, Gattorno M, Sitia R and Rubartelli A: Progressive waves of IL-1b release by primary human monocytes via sequential activation of vesicular and gasdermin D-mediated secretory pathways. Cell Death Dis 9: 1088, 2018.

16. Shen J, Xu S, Zhou H, Liu H, Jiang W, Hao J and Hu Z: IL-1 $\beta$ induces apoptosis and autophagy via mitochondria pathway in human degenerative nucleus pulposus cells. Sci Rep 7: 41067, 2017.

17. Baker KJ, Houston A and Brint E: IL-1 family members in cancer; two sides to every story. Front Immunol 10: 1197, 2019.

18. Coutinho LG, Grandgirard D, Leib SL and Agnez-Lima LF: Cerebrospinal-fluid cytokine and chemokine profile in patients with pneumococcal and meningococcal meningitis. BMC Infect Dis 13: 326, 2013.

19. Thobakgale C, Naidoo K, McKinnon LR, Werner LR, Werner L, Samsunder N, Karim SA, Ndung'u T, Altfeld M and Naidoo K: Interleukin 1-beta (IL-1 $\beta$ ) production by innate cells following TLR stimulation correlates with TB recurrence in ART-treated HIV-infected patients. J Acquir Immune Defic Syndr 74: 213-220, 2017.

20. Kawasaki $\mathrm{T}$ and Kawai $\mathrm{T}$ : Toll-like receptor signaling pathways Front Immunol 5: 461, 2014.

21. Molteni M, Bosi A and Rossetti C: Natural products with Toll-like receptor 4 antagonist activity. Int J Inflam 2018: 2859135, 2018.

22. Raby AC, González-Mateo GT, Williams A, Topley N, Fraser D, López-Cabrera M and Labéta MO: Targeting Toll-like receptors with soluble Toll-like receptor 2 prevents peritoneal dialysis solution-induced fibrosis. Kidney Int 94: 346-362, 2018.

23. Zhang G and Ghosh S: Toll-like receptor-mediated NF-kappaB activation: A phylogenetically conserved paradigm in innate immunity. J Clin Invest 107: 13-19, 2001.

24. Liu YX, Wang GD, Wang X, Zhang YL and Zhang TL: Effects of TLR-2/NF- $\kappa \mathrm{B}$ signaling pathway on the occurrence of degenerative knee osteoarthritis: An in vivo and in vitro study. Oncotarget 8: 38602-38617, 2017.

25. Zheng DY, Zhou M, Jin J, He M, Wang Y, Du J, Xiao XY, Li PY, Ye AZ, Liu J and Wang TH: Inhibition of P38 MAPK downregulates the expression of IL-1 $\beta$ to protect lung from acute injury in intestinal ischemia reperfusion rats. Mediators Inflamm 2016: 9348037, 2016

26. Matou-Nasri S, Rhaban Z, Al-Baijan H, Al-Eidi H, Yahya WB, Al Abdulrahman A, Almobadel N, Alsubeai M, Al Ghamdi S, Alaskar A, et al: CD95-mediated apoptosis in Burkitt's lymphoma B-cells is associated with Pim-1 down-regulation. Biochim Biophys Acta Mol Basis Dis 1863: 239-252, 2017.

27. Jablonska E and Marcinczyk M: TLR2 expression in relation to IL- 6 and IL-1 beta and their natural regulators production by PMN and PBMC in patients with Lyme disease. Mediators Inflamm 2006: 32071, 2006.

28. Goral J and Kovacs EJ: In vivo ethanol exposure down-regulates TLR2-, TLR4-, and TLR9-mediated macrophage inflammatory response by limiting p38 and ERK1/2 activation. J Immunol 174: 456-463, 2005

29. Jin J, Samuvel DJ, Zhang X, Li Y, Lu Z, Lopes-Virella MF and Huang Y: Coactivation of TLR4 and TLR $2 / 6$ coordinates an additive augmentation on IL-6 gene transcription via p38MAPK pathway in U937 mononuclear cells. Mol Immunol 49: 423-432, 2011.

30. Auron PE and Webb AC: Interleukin-1: A gene expression system regulated at multiple levels. Eur Cytokine Netw 5: 573-592, 1994

31. Eggesb $\varnothing$ JB, Hjermann I, Lund PK, Jo $\varnothing$ GB, Ovsteb $\varnothing$ R and Kierulf P: LPS-induced release of IL-1 beta, IL-6, IL-8, TNF-alpha and SCD14 in whole blood and PBMC from persons with high or low levels of HDL-lipoprotein. Cytokine 6: 521-529, 1994.

32. Harrison LM, van den Hoogen C, van Haaften WC and Tesh VL: Chemokine expression in the monocytic cell line THP-1 in response to purified shiga toxin 1 and/or lipopolysaccharides. Infect Immun 73: 403-412, 2005.

33. Murphy M, Xiong Y, Pattabiraman G, Qiu F and Medvedev AE: Pellino-1 positively regulates Toll-like receptor (TLR) 2 and TLR4 signaling and is suppressed upon induction of endotoxin tolerance. J Biol Chem 290: 19218-19232, 2015.

34. Karwaciak I, Gorkiewicz M, Bartosz G and Pulaski L: TLR2 activation induces antioxidant defence in human monocyte-macrophage cell line models. Oncotarget 8: 54243-54264, 2017.

35. Mohagheghpour N, Waleh N, Garger SJ, Dousman L, Grill LK and Tusé D: Synthetic melanin suppresses production of proinflammatory cytokines. Cell Immunol 199: 25-36, 2000. 
36. Liu Y, Wang Y, Yamakuchi M, Isowaki S, Nagata E, Kanmura Y, Kitajima I and Maruyama I: Upregulation of Toll-like receptor 2 gene expression in macrophage response to peptidoglycan and high concentration of lipopolysaccharide is involved in NF-kappaB activation. Infect Immun 69: 2788-2796, 2001.

37. Wan J, Shan Y, Fan Y, Fan C, Chen S, Sun J, Zhu L, Qin L, Yu M and Lin Z: NF- $\kappa$ B inhibition attenuates LPS-induced TLR4 activation in monocyte cells. Mol Med Rep 14: 4505-4510, 2016.

38. El-Obeid A, Alajmi H, Harbi M, Yahya WB, Al-Eidi H, Alaujan M, Haseeb A, Trivilegio T, Alhallaj A, Alghamdi S, et al: Distinct anti-proliferative effects of herbal melanin on human acute monocytic leukemia THP-1 cells and embryonic kidney HEK293 cells. BMC Complement Med Ther 20: 154, 2020

39. Ibrahim H, Barrow P and Foster N: Transcriptional modulation by VIP: A rational target against inflammatory disease. Clin Epigenetics 2: 213-222, 2011.
40. Peroval MY, Boyd AC, Young JR and Smith AL: A critical role for MAPK signalling pathways in the transcriptional regulation of Toll like receptors. PLoS One 8: e51243, 2013.

41. Li JY, Liu Y, Gao XX, Gao X and Cai H: TLR2 and TLR4 signaling pathways are required for recombinant Brucella abortus BCSP31-induced cytokine production, functional upregulation of mouse macrophages, and the Th1 immune response in vivo and in vitro. Cell Mol Immunol 11: 477-494, 2014.

42. Mukherjee S, Karmakar S and Babu SP: TLR2 and TLR4 mediated host immune responses in major infectious diseases: A review. Braz J Infect Dis 20: 193-204, 2016.

(2)(9) This work is licensed under a Creative Commons Attribution-NonCommercial-NoDerivatives 4.0 International (CC BY-NC-ND 4.0) License. 